UDC [378.6:656.7]:004

DOI 10.33251/2522-1477-2021-9-27-33

DANYLKO Oksana,

Candidate of Pedagogical Sciences, Associate Professor of the Department of Information Technologies, Flight Academy of the National Aviation University

ORCID 0000-0002-7942-8012

TYMOSHENKO Anna,

Senior Lecturer of the Department of Information

Technologies, Flight Academy of the National Aviation

University

ORCID 0000-0003-2411-497X

SAGANOVSKA Larysa,

Senior Lecturer of the Department of Information

Technologies, Flight Academy of the National Aviation

University

ORCID 0000-0002-2560-4383

IVLIIEV Anatolii, graduate student Flight Academy of the National Aviation University.

ORCID 0000-0002-2405-4738

\title{
FORMS AND METHODS OF ORGANIZATION OF SELF-ASSISTED WORK IN THE PROCESS OF PROFESSIONAL TRAINING OF THE FLIGHT OPERATOR MANAGERS
}

The article shows the features of self-training of future flight operator specialists. The forms and methods of organizing independent work in the process of professional training of future flight opertor managers in conditions of distance learning have been determined and characterized. The authors focused on the organization of independent work of future flight operator managers in conditions of distance learning using information technologies.

Key words: independent work, forms, methods, future flight operator managers, distance learning, information technology.

The problem set. The process of training at a higher aviation institution is increasingly based on the intensification of cognitive activity and high independence of cadets, as the challenges of today require independent mastering of a large amount of knowledge by cadets. The problem of organizing independent training of cadets today, in a pandemic, is more important than ever because deep strong knowledge and stable skills can be acquired by cadets only if a fairly active and purposeful independent educational and cognitive activities.

The aim of the article is to determine the forms and methods of organizing independent work in the process of professional training of future air traffic controllers in terms of distance learning.

The analysis of recent researches and publications. Analysis of scientific sources (G. Vlasyuk, V. Kozakov, A. Kokareva, I. Lerner, A. Aleksyuk, O. Hrybok) shows that there is a tendency to consider the concept of "independent work" as an effective means of forming interests, knowledge, skills, and abilities. personality. The effectiveness of independent work is explained by scientists by the fact that it is their own intellectual and cognitive work of students with the "appropriation" of their skills, abilities, motives, personal qualities, and more. 
Scientists interpret independent work as a means of forming in future professionals, first of all, readiness for self-education, emphasizing the focus of this work on the development of creative abilities of students.

We fully adhere to the position of G. Vlasyuk, according to which the fundamentally important purpose of independent work is to ensure strong assimilation of theoretical knowledge by students, the actualization of their cognitive motivation, the formation of professional skills, independence, activity [3].

P. Podkasisty considers independent work as an effective means of educational and scientific knowledge in the training of future professionals. This work forms in students the ability to organize their own work to achieve goals in professional activities [10].

Outline of the main research material. Independent work involves the application of an individual approach to the teaching of professional disciplines, it is always performed following the plan of professional training of future professionals under the guidance of a teacher [5].

In this aspect, L. Kaidalova rightly emphasizes that independent work requires clear planning, organization, and control of students' cognitive activity in the classroom and extracurricular time. [6, p. 68].

From the scientific point of view of A. Aleksyuk, independent work involves the processing by students of scientific information presented in textbooks, manuals, articles, monographs, dissertations, and more. Thus, independent work involves not only the study of various documents, problem-solving, individual tasks, as well as the involvement of future professionals in scientific work [1, p. 334].

As practice shows, students most value in the organization of independent work the possibility of creative self-realization, learning new material in the context of additional classes, the development of a culture of thinking, individual qualities, the ability to express their own opinions. Along with this, the most common shortcomings in the independent work of students are such as the lack of ability to work independently, to connect theoretical knowledge with practice [2].

Analysis of scientific and pedagogical literature allows us to identify the following aspects of the problem of independent work of cadets:

- independent work is a means of deep and strong assimilation of basic knowledge, formation of skills and abilities in the studied subject;

- independent work contributes to the education of cognitive independence and activity of the individual;

- $\quad$ success of independent work

- determined by the degree of mastery of special techniques of educational work by those who study;

- independent work is the basis for the formation of the need for constant replenishment of their knowledge, readiness for self-education;

- independent work is a means of forming the independence of educational and cognitive activities [7, p. 11].

Among the specific features of the formation of independent cognitive activity can be identified several, which is related to the peculiarities of the profession of air traffic controller (SDA). The manager came to ensure the effective regulation of the team of textbooks for the preparation of the preparation and execution of the raft, drawing up plans of rafts and submits them to the subordinate unit of maintenance, training and control of ensuring the implementation of the interrogation of unfounded interrogations. Such work requires unconditional responsibility, discipline, initiative and the need for constant updating of professional knowledge. A modern air traffic controller is also a creative person with the skills of a researcher who can find and highlight the most important methodological principles, evaluate the basic parameters and properties of technical aviation systems, can present them in models and use the latest set of methods and tools. clarification of the correctness of the selected calculation schemes, design forms, materials and technologies that ensure flight safety. 
Independent work of future flight specialists requires daily work of cadets, which is performed following the tasks developed by the teacher. These tasks include, first of all, active selfpreparation of cadets for classroom classes, dedication, responsibility, organization, etc.

In the scientific and pedagogical literature, scientists identify the main types of independent work of students, namely: research and educational work, practical classes, sections and individual work of students [2].

The basis for independent work is an educational and theoretical course, a set of knowledge acquired by cadets. During the assignment, cadets receive instructions on how to complete them, guidelines, aeronautical information collections, ICAO thematic documents, flight plan forms (FPL) and NOTAMs, aeronautical chart collections, and more.

The purpose of independent work is the formation of the cadet's independence, his skills, knowledge, abilities, which is carried out indirectly through the content and methods of all types of training. Performing independent work allows the future specialist to consolidate and deepen the theoretical knowledge gained in the study of individual topics, learn to work independently with different sources of information, analyze and interpret materials of aviation literature, use in their professional activities civil aviation practice, research skills, etc. cadets are presented in table 1.

Teaching methods play an important role in the independent training of future professionals. Well-known methods of independent work include reading, taking notes, performing exercises (solving problems), etc. It is clear that in a pandemic and the introduction of distance learning, the ability of cadets to carry out independent work will improve if it is organized as a holistic system based on a well-thought-out and methodically organized educational and developmental information environment through the use of real and virtual tools. Thus "The basis of the educational process in distance learning is purposeful and controlled independent work of the student, who can study in a convenient place, on an individual schedule, having a set of special teaching aids and coordinated contact with the teacher" by means of telecommunications $[9$, p. 358359]. The World Wide Web is a way of organizing an educational and developmental information environment that creates conditions for the organization of independent work of cadets in the process of their professional training.

Cloud technologies, as a dynamically scalable free way to access external computing information resources in the form of services provided via the Internet, are now an integral part of the training process for future flight operator managers.

\section{Forms of organizing independent work of cadets}

Table 1

\begin{tabular}{|c|c|}
\hline Types and forms of independent work & Forms of control and reporting \\
\hline \multicolumn{2}{|c|}{ Preparation for current classes } \\
\hline $\begin{array}{l}\text { Elaboration of the listened lecture material, } \\
\text { as well as basic and auxiliary aviation literature. } \\
\text { Active participation in various types of classes. }\end{array}$ & $\begin{array}{l}\text { Elaboration of the listened lecture material, as } \\
\text { well as basic and auxiliary aviation literature. Active } \\
\text { participation in various types of classes. }\end{array}$ \\
\hline $\begin{array}{l}\text { Study of separate questions provided for } \\
\text { independent working out. Checking the } \\
\text { correctness of the tasks. }\end{array}$ & $\begin{array}{l}\text { Study of separate questions provided for } \\
\text { independent working out. Checking the correctness } \\
\text { of the tasks. }\end{array}$ \\
\hline $\begin{array}{l}\text { Execution and writing of tasks and other } \\
\text { works. Checking the correctness of the tasks in } \\
\text { the classroom. }\end{array}$ & $\begin{array}{l}\text { Execution and writing of tasks and other works. } \\
\text { Checking the correctness of the tasks in the } \\
\text { classroom. }\end{array}$ \\
\hline $\begin{array}{l}\text { Preparation for practical and laboratory } \\
\text { classes. Active participation in practical and } \\
\text { laboratory classes. }\end{array}$ & $\begin{array}{l}\text { Preparation for practical and laboratory classes. } \\
\text { Active participation in practical and laboratory } \\
\text { classes. }\end{array}$ \\
\hline $\begin{array}{l}\text { Preparation for the current control. Writing } \\
\text { tests, testing, etc. }\end{array}$ & $\begin{array}{l}\text { Preparation for the current control. Writing } \\
\text { tests, testing, etc. }\end{array}$ \\
\hline
\end{tabular}




\section{Search and analytical work}

Search and review of literature sources, materials of aviation collections on a given topic Consideration of prepared materials during classroom classes

Writing an abstract, abstract of the report, individual task, etc. Discussion of the abstract, report, individual educational and research task during classroom classes

Analysis of a specific practical situation, aviation event, filling in various types of aeronautical documentation, including FPL, NOTAM. Consideration of prepared materials, participation in solving situational problems, etc.
Search and review of literature sources, materials of aviation collections on a given topic Consideration of prepared materials during classroom classes

Writing an abstract, abstract of the report, individual task, etc. Discussion of the abstract, report, individual educational and research task during classroom classes

Analysis of a specific practical situation, aviation event, filling in various types of aeronautical documentation, including FPL, NOTAM. Consideration of prepared materials, participation in solving situational problems, etc.

Obtaining a research task from a teacher, supervisor, etc. Current control, presentation at departmental and interdepartmental seminars, scientific conferences, etc.

Work in small groups, preparation of group reports Consideration of the prepared materials, participation in the decision of situational problems

Obtaining a research task from a teacher, supervisor, etc. Current control, presentation at departmental and interdepartmental seminars, scientific conferences, etc.

Work in small groups, preparation of group reports Consideration of the prepared materials, participation in the decision of situational problems

Collectively, cloud and distance technologies provide the introduction of asynchronous learning, when the teacher teaches the relevant materials: lectures, practical assignments, tests, etc., access to which the cadet makes at any time convenient for him. Restrictions may relate only to the deadline for studying the topic, performing tasks for independent work, reporting, and so on.

When selecting and combining teaching methods for the effective implementation of the independent work of cadets should be guided by the following criteria:

- $\quad$ each method must provide the degree and degree of self-disclosure of cadets;

- each method must meet the needs of the cadet in new information;

- each method of teaching should promote the communicative adaptation of the cadet through the improvement of communication skills (orally or in writing);

- each method should help the cadet in self-expression (creative orientation) [4], etc.

The organization of independent work of future air traffic controllers in the conditions of distance learning with the use of information technologies can be as follows:

- coordination and exchange of educational information between teachers and cadets (academy website, Moodle learning management system, GoogleMEET service, other cloud technologies and electronic applications, etc.);

- on the part of the teacher providing "electronic information portfolio" (electronic textbooks, manuals, dictionaries, reference books, guidelines, recommended information retrieval and library network resources, electronic forms NOTAM, FPL, etc.);

- use of electronic teaching aids such as electronic laboratory workshops "Flight Plan", "Completion of applications for the use of PE of Ukraine", "Completion of applications for flights";

- use of mobile learning technologies (m-learning) together with mobile devices and blended-learning technologies, such as BYOD technology (BringYourOwnDevice);

- use of computer diagnostic programs and self-monitoring of the level of knowledge acquisition by cadets (Google-forms, mobile application Plickers, etc.); use of a computer program for recording performance and attending classes of cadets (electronic journal on Google-disk);

- independent development of "electronic portfolio" of cadets under the guidance of teachers (for direct and feedback with airlines);

- on the example of information and educational platform (MOODLE, GoogleClassroom) introduction of a new format of communication "cadet - teacher", "cadet - group", "cadet - cadet". 
Conclusions and areas for further search. In today's conditions, the main reserve for improving the efficiency of the training process and the quality of training of future air traffic controllers is the rational organization of their independent work. Properly organized independent work allows you to:

- $\quad$ to penetrate deeply into the main content of the disciplines studied;

- consciously and firmly master the system of scientific knowledge;

- to develop their cognitive abilities as much as possible, to form a culture of mental work;

- $\quad$ to acquire professional qualities and as a whole to master a speciality thoroughly;

- to develop such important personal qualities as diligence and perseverance, stubbornness and the ability to distribute their strengths and ways to achieve the goal.

The combination of cloud technologies (mobility of cadets, information saturation of educational space, use of specialized software, etc.) and principles of distance learning, using information and communication innovations allows solving key organizational, educational, controlling and corrective tasks of the process of organizing independent work of future dispatchers.

It should be emphasized that the forms and methods of independent work in the training of future air traffic controllers should be constantly improved, thereby encouraging future professionals to search independently in the process of continuous self-education and laying the foundation for readiness for further professional activity.

\section{References}

1. Aleksyuk, A.M. (1998). Pedahohika vyshchoyi osvity Ukrayiny: Istoriya. Teoriya. [Pedagogy of higher education in Ukraine: History. Theory]. K.: Lybid' [In Ukrainian].

2. Bondarenko, E.V. (2017). Organizatsia samostiynoyi roboty maybutnikh sudnovodiyiv u protsesi formuvanny profesiyno-movlennyevoyi kompetentnosti [Individual work as a formation mean of professional and speech competence of future navigators] Retrieved from: http://journals.hnpu.edu.ua/index.php/sciencemeans/ article/download/690/787 (date of the application: 16.01.2021) [In Ukrainian].

3. Vlasyuk, H.I. (2012). Pedahohichni zasady vykhovannya samostiynosti maybutnikh fakhivtsiv iz fizychnoho vykhovannya. [Pedagogical principles of education of independence of future specialists in physical education] Retrieved from: http://www.irbis-nbuv.gov.ua/cgibin/irbis_nbuv/cgiirbis_64.exe?I21DBN=LINK\&P21DBN=UJRN\&Z21ID=\&S21REF=10\&S21CN $\mathrm{R}=20 \& \mathrm{~S} 21 \mathrm{STN}=1 \& \mathrm{~S} 21 \mathrm{FMT}=\mathrm{ASP}$ meta\&C21COM=S\&2_S21P03=FILA=\&2_S21STR=Fvs_201 2_2_13 (date of the application: 16.01.2021) [In Ukrainian].

4. Hrybok, O.P. (2007). Formuvannya tvorchoyi piznaval'noyi samostiynosti kursantiv VVNZ: rezul'taty doslidzhen' ta yikh analiz. [Formation of creative cognitive independence of university cadets: research results and their analysis]. Naukovi zapysky Ternopil's'koho derzhavnoho pedahohichnoho universytetu. Seriya: Pedahohika. 2007. № 4. s. 29-33. [In Ukrainian]

5. Ievdokymov, V.I. (2004). Samostiina robota studentiv [Independent work of students]. Kharkiv: Vyd-vo KhDHU. Retrieved from: http://journals.hnpu.edu.ua/index.php/sciencemeans/ article/view/690 (date of the application: 16.01.2021) [In Ukrainian].

6. Kaydalova, L.H. (2010). Orhanizatsiya ta kontrol' samostiynoyi roboty studentiv. [Organization and control of independent work of students.]. Pedahohika, psykholohiya ta medykobiolohichni problemy fizychnoho vykhovannya i sportu. 2010. №1. P. 67-70. Retrieved from: https://dspace.nuph.edu.ua/handle/123456789/2926 (date of the application: 16.01.2021) [In Ukrainian].

7. Kozakov, V.A. (1990). Samostoyatel'naya rabota studentov i yeyo informatsionnometodicheskoye obespecheniye [Independent work of students and its informational and methodological support.]. Uchebnoye posobiye. Kiyev: Vysshaya Shkola, 1990. 248 s. [In Russian].

8. Kokaryeva, A.M. (2015). Orhanizatsiya samostiynoyi roboty studentiv v protsesi profesiynoyi pidhotovky [Organization of independent work of students in the process of professional training]. Retrieved from: http://jrnl.nau.edu.ua/index.php/VisnikPP/ article/viewFile/10228/13429 (date of the application: 16.01.2021) [In Ukrainian]. 
9. Kuz'mins'kyy, A.I. (2005). Pedahohika vyshchoyi shkoly [Pedagogy of higher school: textbook]: navch. posib. K.: Znannya, 2005. 486 s. [In Ukrainian].

10. Pidkasistyy, P.I. (2004). Organizatsiya uchebno-poz navatel'noy deyatel'nosti studentov [Organization of educational and educational activities of students]. [Tekst]: uch. pos. M.: Pedagogicheskoye obshchestvo Rossii. 2004. 112 s. [In Russian].

\section{Список використаних джерел}

1. Алексюк А. М. Педагогіка вищої освіти України: Історія. Теорія. К.: Либідь 1998. $558 \mathrm{c}$.

2. Бондаренко Є. В. Організація самостійної роботи майбутніх судноводіїв у процесі формування професійно-мовленнєвої компетентності. URL: http://journals.hnpu.edu.ua/index. php/sciencemeans/article/download/690/787 (дата звернення: 16.01.2021).

3. Власюк Г. I. Педагогічні засади виховання самостійності майбутніх фахівців із фізичного виховання. URL: http://www.irbis-nbuv.gov.ua/cgi-bin/irbis_nbuv/cgiirbis_64.exe? $\mathrm{I} 21 \mathrm{DBN}=\mathrm{LINK} \& \mathrm{P} 21 \mathrm{DBN}=\mathrm{UJRN} \& Z 21 \mathrm{ID}=\& \mathrm{~S} 21 \mathrm{REF}=10 \& \mathrm{~S} 21 \mathrm{CNR}=20 \& \mathrm{~S} 21 \mathrm{STN}=1 \& \mathrm{~S} 21 \mathrm{FMT}=$ ASP_meta\&C21COM=S\&2_S21P03=FILA=\&2_S21STR=Fvs_2012_2_13 (дата звернення: 16.01.2021).

4. Грибок О. П. Формування творчої пізнавальної самостійності курсантів ВВНЗ: результати досліджень та іх аналіз. Наукові записки Тернопільського державного педагогічного університету. Серія: Педагогіка. 2007. № 4. с. 29-33.

5. Свдокимов В. I. Самостійна робота студентів. Харків: Вид-во ХДГУ. URL: http://journals.hnpu.edu.ua/index.php/sciencemeans/article/view/690 (дата звернення: 16.01.2021).

6. Кайдалова Л. Г. Організація та контроль самостійної роботи студентів. Педагогіка, психологія та медико-біологічні проблеми фізичного виховання і спорту. 2010. №1. С. 67-70. URL: https://dspace.nuph.edu.ua/handle/123456789/2926 (дата звернення: 16.01.2021).

7. Козаков В. А. Самостоятельная работа студентов и её информационнометодическое обеспечение: учебное пособие. Киев: Высшая Школа, 1990. 248 с.

8. Кокарєва А. М. Організація самостійної роботи студентів в процесі професійної підготовки. URL: http://jrnl.nau.edu.ua/index.php/VisnikPP/article/viewFile/10228/13429 (дата звернення: 16.01.2021).

9. Кузьмінський А. І. Педагогіка вищої школи: навч. посіб. К.: Знання, 2005. 486 с.

10. Пидкасистый П. И. Организация учебно-поз навательной деятельности студентов [Текст]: уч. пос. М.: Педагогическое общество России, 2004. 112 с.

ДАНИЛКО Оксана Григорівна, кандидат педагогічних наук, доцент кафедри інформаційних технологій, Льотна академія Національного авіаційного університету;

ТИМОШЕНКО Ганна Сергіївна, старший викладач кафедри інформаційних технологій, Льотна академія Національного авіаційного університету;

САГАНОВСЬКА Лариса Анатоліївна, старший викладач кафедри інформаційних технологій, Льотна академія Національного авіаційного університету;

ІВЛІСВ Анатолій Миронович, аспірант, Льотна академія Національного авіаційного університету.

\section{ФОРМИ ТА МЕТОДИ ОРГАНІЗАЦІЇ САМОСТІЙНОЇ РОБОТИ В ПРОЦЕСІ ПРОФЕСІЙНОЇ ПІДГОТОВКИ ДИСПЕТЧЕРІВ ІЗ ЗАБЕЗПЕЧЕННЯ ПОЛЬОТІВ}

Анотація. Стаття має за мету висвітлити особливості самостійної підготовки майбутніх фахівців із забезпечення польотів. Проблема організації самостійної підготовки курсантів сьогодні, в умовах пандемії, актуальна як ніколи, оскільки глибокі міцні знання й стійкі вміння можуть здобуватися курсантами лише за умови досить активної та иілеспрямованої самостійної навчально-пізнавальної діяльності. Самостійна робота 
майбутніх фахівців із забезпечення польотів вимагає від курсантів щзоденної праці, щуо виконується відповідно до розроблених викладачем завдань. Виконання самостійної роботи дає можливість майбутньому фахівцю закріпити та поглибити теоретичні знання, отримані в процесі вивчення окремих тем, навчитися самостійно працювати з різними інформаційними джерелами, аналізувати та інтерпретувати матеріали авіаційної літератури, використовувати у власній професійній діяльності практику роботи органів ичивільної авіачії, отримати навички дослідної роботи тощэо.

Враховуючи специфіку професійної підготовки диспетчерів із забезпечення польотів, нами було представлено форми організації їх самостійної роботи, щзо, в свою чергу, поділяються безпосередньо на види та форми самостійної роботи, та форми контролю та звітності.

Стосовно методів організації самостійної роботи, то зрозуміло, щуо в умовах пандемії та запровадження дистаниійного навчання здатність курсантів до здійснення самостійної роботи буде вдосконалюватися за умови ї̈ організачії через використання інформаційних технологій. Такими методами можуть бути: координація й обмін навчальною інформацією між викладачами та курсантами (сайт академії, система управління навчанням "Моодlе», сервіс Google MEET, інші хмарні технологї та електронні додатки тощо); з боку викладача надання «електронного інформаційного портфеля» (електронні підручники, посібники, документи ICAO, аеронавігащійна інформація, NOTAM, flight-плани тощо); використання технологій мобільного навчання (m-learning) разом із мобільними пристроями та технологіями змішаного навчання (blended-learning), наприклад технологія ВYOD (Bring Your Own Device); використання комп'ютерних програм діагностики та самоконтролю рівня засвоєння знань курсантами (Google-форми, мобільний додаток Plickers тощо); використання комп'ютерної програми обліку успішності та відвідування занять курсантів (електронний журнал на Google-диску); розробка «електронного портфоліо» курсантами (для прямого та зворотнього зв'язку із авіакомпаніями).

Таке поєднання форм та методів дозволить вирішити ключові завдання процесу організаиії самостійної роботи майбутніх диспетчерів із забезпечення польотів.

Ключові слова: самостійна робота, форми, методи, майбутні диспетчери із забезпечення польотів, дистанційне навчання, інформаційні технології. 